Гідроелектростаниї є однією з форм поновлюваних джерел енергї, що надходить з проточної води. Турбіна використовується для запуску генератора і перетворення механічної енергї̈ в електричну. Колесо турбіни розташоване всередині корпусу турбіни $і$ обертає привідний вал. Однією з найбільи поширених турбін є турбіна поперечного потоку. На характер потоку води, що протікає через порожнину ротора турбіни поперечного потоку, впливає кількість активних лопатей ротора, об які б'ється вода з сопла турбіни. Вважалося, що відмінність в характері потоку пов'язане з відмінностями в продуктивності трьох моделей турбін. Візуалізації потоку води, що проходить через порожнину ротора турбіни поперечного потоку, були взяті з експериментального дослідження робочих характеристик трьох моделей турбіни поперечного потоку, розрахованих на одні і ті ж значення витрати, діаметрів ротора і швидкостей обертання, але кожна модель турбіни має різні значення ширини ротора $і$ дуги входу сопла. Ширина сопла i ротора розрахована як функція дуги входу сопла, тому чим менше ширина пари ротора $і$ сопла, тим більше дуга входу сопла $і$ навпаки. Візуалізачії потоку води, що проходить через турбіну, були вивчені за допомогою порожнини турбіни поперечного потоку. Три моделі були випробувані з однаковим напором $і$ з однаковим витратою на ивидкості 50, 100, 150, 250, 300 i 500 об/хв. Були зроблені знімки води, що проходить через порожнину роторів моделі турбіни, для визначення умов потоку, $i$ була розрахована ефективність моделей для відображення продуктивності турбіни. Зображення зроблені в межах 10 см і паралельно турбіні. Моделі турбіни поперечного потоку були спроектовані з діаметром ротора по 197 мм кожен $і$ відношенням діаметра ротора до довжини ротора 1:2. Одна сторона кожного торцевого диска моделі турбіни була зроблена з прозорого матеріалу Перспекс, що полегшувало дослідику спостереження за режимом потоку води під час протікання всередину ротора. Умови потоку води, що проходить через порожнину турбінних коліс, були сфотографовані за допомогою камери Нікон, оснащеної галогеновою лампою потужністю $1000 \mathrm{Bm}$ для фіксації різниці в характері потоку між трьома моделями турбіни. Дуги входу сопла, що використовуються в даному експериментальному дослідженні, становили $75^{\circ}, 90^{\circ}$ i $120^{\circ}$. Крім того, сопло кожної моделі має однакову площу поперечного перерізу, а кришка має радіус кривизни, центрований по осі вала. Очікувалося, що така кривизна кришки сопла зможе доставляти воду в кращому напрямку, а також в режимі ї̈ потоку, коли вода надходить в ротор турбіни. Величина дуги входу сопла визначає кількість активних лопатей, об які б'ється струмінь води, що виходить з сопла. Ці умови впливають на картину потоку води в момент проходження через порожнину колеса турбіни. Передбачалося, що даний режим потоку впливає на робочі характеристики турбіни поперечного потоку

Ключові слова: дуга входу сопла, режим потоку, робочі характеристики турбіни поперечного потоку

\section{FLOW VISUALIZATION OF WATER JET PASSING THROUGH THE EMPTY SPACE OF CROSS- FLOW TURBINE RUNNER}

\author{
Djoko Sutikno \\ Doctorate* \\ E-mail: bp_djoko@ub.ac.id \\ Rudy Soenoko
}

Doctor of Technological Sciences,

Professor*

E-mail: rudysoen@ub.ac.id

Sudjito Soeparman

Professor*

E-mail: sudjitospn@ub.ac.id

S I a met Wah yud i

Doctor of Technological Sciences,

Associate Professor*

E-mail: slamet_w72@ub.ac.id

*Department of Mechanical

Engineering

Brawijaya University

JI. Mayjen Haryono, 167, Malang,

Indonesia, 65145

\section{Introduction}

The pattern of water jet flowing throughout the empty space of the runner of the cross-flow turbine is influenced by the number of active runner blades pounded by water from the turbine nozzle. The numbers of active blades are determined by how large the nozzle entry arc of the crossflow turbine, the larger nozzle entry arc resulted in the greater number of active blades [1-3]. The visualizations of the flow of water passing through the empty space of three cross-flow turbine models were being photographed at the time of experimental research to investigate the performance characteristics of the turbine models where each model is designed for the same flow rate, the same runner diameter and the same rotational speed [2-6]. However, each model has different runner widths and different nozzle entry arcs. In addition, the width of the runner is a function of nozzle entry arc. The first model had a $75^{\circ}$ nozzle entry arc, the second model had a nozzle entry arc of $90^{\circ}$ and the third model had a $120^{\circ}$ nozzle entry arc. In addition, since the nozzle entry arcs determine the number of passages built by the runner blade, the larger nozzle entry arc the more passages burted by water jets exit from the turbine nozzle [7-9]. The difference in the flow patterns was believed having a relation to the performance differences of the three turbine models. Runners should be formed accordingly so that changes occur in the momentum on the working fluid of the water. The turbine consists of a cylindrical water wheel or runner with 
a horizontal shaft, composed of numerous blades, arranged radially and tangentially. This cross-flow turbine has an upright flow direction straight with the turbine axis (radial). The turbine has a pointing device called the nozzle so that the free gap with blades around the wheel. Visualization of the turbine cross-flow runner is needed to analyze the performance of the turbine.

\section{Literature review and problem statement}

A cross-flow water turbine is made, the generator energy source comes from water energy (potential energy and kinetic energy). The potential energy of water changes to the kinetic energy of water, then the kinetic energy of this water is converted by water turbines into mechanical energy (rotation of the turbine shaft) [1-7]. Cross-flow water turbines are usually a type of radial impulse water turbine. The flow of water enters the turbine through a nozzle with a rectangular cross-section. The flow passes through the turbine blade with twice relative direction perpendicular to the turbine shaft. In this case, there is no axial direction flow, so there are no forces acting in the direction of the turbine shaft. The rotation of the turbine shaft is converted by a generator into electrical energy (electrical energy). Cross-flow turbines as drivers are chosen because the construction is simple and easy to apply $[4,5]$. This study uses a vertical shaft cross-flow turbine, a blade shaped blade, and turbines are arranged in two levels in order to capture more flow in order to increase the rotational power produced. The purpose of this study is the realization of a cross-flow turbine design that efficiently captures water energy, producing optimal power [9-11]. The numbers of active blades are determined by how large the nozzle entry arc of the cross-flow turbine, the larger nozzle entry arc resulted in the greater number of active blades [9-12]. The visualizations of the flow of water passing through the empty space of three cross-flow turbine models were being photographed at the time of experimental research to investigate the performance characteristics of the turbine models where each model is designed for the same flow rate, the same runner diameter and the same rotational speed [13, 14]. The nozzle entry arcs determine the number of passages built by the runner blade, the larger nozzle entry arc the more passages burted by water jets exit from the turbine nozzle. The visualizations of the flow of water passing through the empty space of three cross-flow turbine models were being photographed at the time of experimental research [15-17].

Therefore, the perspective of the study is to investigate the performance characteristics of the turbine models where each model is designed for the same flow rate, the same runner diameter and the same rotational speed. The difference in the flow patterns was believed having a relation to the performance differences of the three turbine models.

\section{The aim and objectives of the study}

The aim of the study is to investigate the performance characteristics of the turbine models where each model is designed for the same flow rate, the same runner diameter and the same rotational speed.

To achieve this aim, the following objectives are accomplished:
- the visualization of the flow of water passing through the empty space of three cross-flow turbine models;

- to design the flow rate of turbine models;

- to design the runner diameter of turbine models;

- to design the rotational speed.

\section{Material, methods and model of research}

The flow visualizations of water passing on the turbine were studied using the empty space of the cross-flow turbine. The three models were tested on the same head and the same flow rate at the speed of 50, 100, 150, 250, 300 and $500 \mathrm{rpm}$.

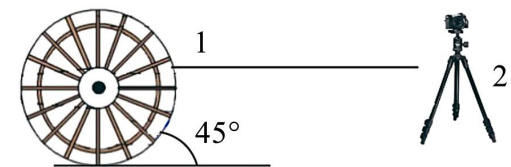

Fig. 1. Experimental set-up: 1 - Turbine; 2 - SLR camera

Fig. 1 shows the experimental set-up. The photos of water flowing through the empty space in the turbine model runners were taken to find out the conditions of flow and the efficiency of the models was calculated to show the performance of the turbine. Images are taken within $10 \mathrm{~cm}$ and parallel to the turbine. The cross-flow turbine models were designed with $197 \mathrm{~mm}$ runner diameter of each and have the ratio of runner diameter to runner length of 1:2. One side of each turbine model end disk was made from transparent media named perspex facilitating the researcher to observe the water flow condition during flowing through inside the runner. The conditions of the flow of water passing through the empty space of turbine wheels were photographed using a Nikon camera equipped with a halłogen lamp having a power of 1000 watts to capture the difference of flow pattern among the three turbine models. The flow conditions and the efficiency of the turbines gathered are used for material discussions.

5. Research results of performance characteristics
of three cross-flow turbine models using nozzle roof
curvature radius centered on shaft axis designed on the
same flow rate, runner diameter and rotational speed

5.1. Visualization of water flowing through empty space inside of turbine runner and efficiency of the models tested at $50 \mathrm{rpm}$

The photographs show a visualization of the trace of water flowing through inside of the turbine models with the entry $\operatorname{arc}$ of $\theta=75^{\circ}, \theta=90^{\circ}$ dan $\theta=120^{\circ}$ at the rotational speed of $50 \mathrm{rpm}$.

The photos of Fig. 2 show the jet of water, leaving the halls of the first stage turbine blade, spread and bump into each other, then hit the shaft during flow through the turbine wheel blank space before reaching the halls of the second stage turbine blade.

The collision that resulted in hydraulic losses of water jet and changes in the direction of the water jet when it enters the halls of the second stage turbine blade, and such conditions are predictable reduces the efficiency of the turbine. Turbine efficiency is the ratio of the horsepower of the turbine shaft and water entering the turbine runner. Based 
on the photographs in Fig. 1 it can be stated that the steady stream of water, leaving the outer side of the turbine wheel with the nozzle that has a 120-degree entry arc spreads larger than the steady stream of water, leaving the outer side of the turbine wheel with the nozzle that has a 90 degree entry arc. Fig. 1 also shows the photographs of the steady stream of water, leaving the outskirt of the turbine wheel with the nozzle that has a 90 degree entry arc deploys larger than the steady stream of water, leaving the outer side of the turbine wheel with the nozzle that has an entry arc of $75^{\circ}$. Each runner has 16 blades, for the same water flow rate, the runner which has the larger nozzle entry arc has more active blade numbers pounded by the jets of water.

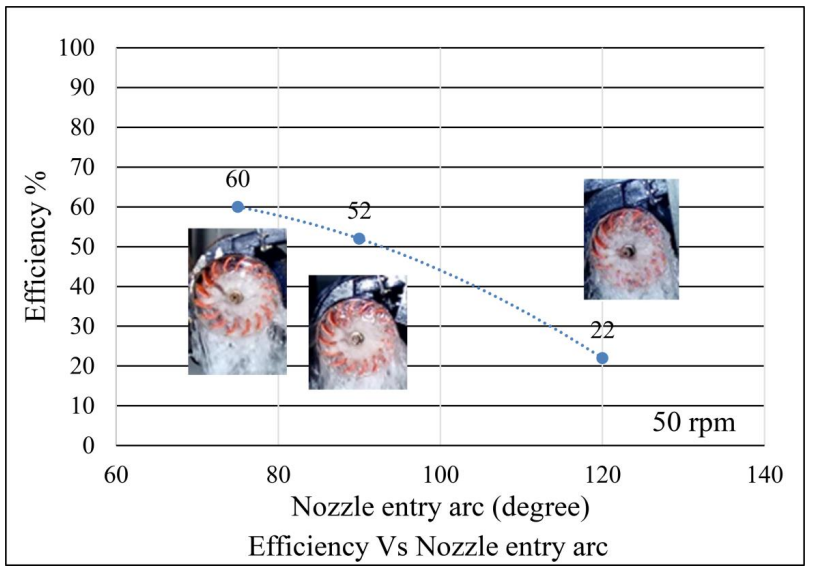

Fig. 2. Efficiency Vs Nozzle entry arc at the rotational speed of $50 \mathrm{rpm}$

The sizes of the nozzle entry arc, the number of active blade passages, the collisions of water jets passing through within the empty spaces inside the turbine wheels and the stream pattern of water leaving the outskirts of the turbine wheels are predicted influencing the turbine efficiencies [10-17]. More collisions of water jets within the empty space inside the wheels create more hydraulic losses and reduce the tangential force component exerted to the runner, and consequently, these conditions lower the shaft power and efficiency of the turbines [16, 18, 19]. The efficiency of the turbines in this experimental study is 60 percent for the turbine with $75^{\circ}$ entry arc, 58 percent for the turbine with $90^{\circ}$ entry arc and 22 percent for the turbine with $120^{\circ}$ entry arc.

5. 2. Visualization of water flowing through empty space inside of turbine runner and efficiency of the models tested at $100 \mathrm{rpm}$

The photographs of the figure show a visualization of the trace of water flowing through inside of the turbine models with the entry arc of $\theta=75^{\circ}, \theta=90^{\circ}$ and $\theta=120^{\circ}$ at a rotational speed of $100 \mathrm{rpm}$.

The photos of Fig. 3 also show the jet of water, leaving the halls of the first stage turbine blade, spread and bump into each other, then hit the shaft during flow through the turbine wheel blank space before reaching the halls of the second stage turbine blade. The collision that resulted in hydraulic losses of water jet and changes in the direction of the water jet when it enters the halls of the second stage turbine blade, and such conditions are predictable reduces the efficiency [20-22].

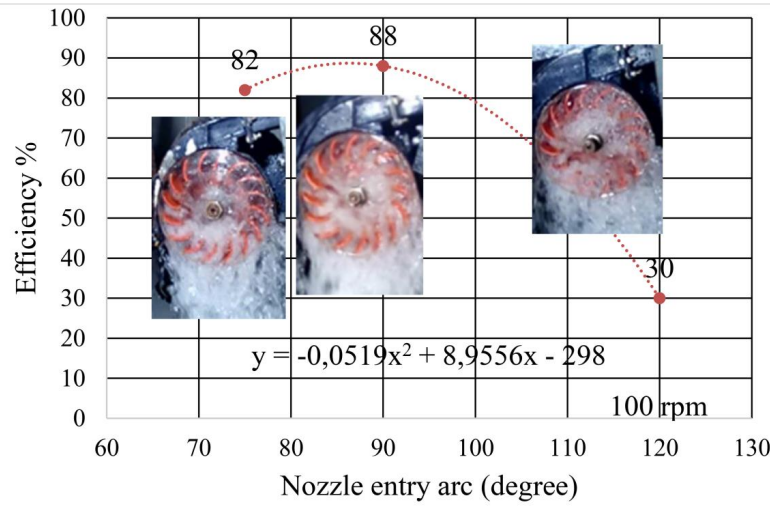

Efficiency Vs Nozzle entry arc

Fig. 3. Efficiency Vs Nozzle entry arc at the rotational speed of $100 \mathrm{rpm}$

The photographs of the figure show a visualization of the trace of water flowing through inside of the turbine models with the entry $\operatorname{arc}$ of $\theta=75^{\circ}, \theta=90^{\circ}$ and $\theta=120^{\circ}$ at a rotational speed of $100 \mathrm{rpm}$.

The photos of Fig. 3 also show the jet of water, leaving the halls of the first stage turbine blade, spread and bump into each other, then hit the shaft during flow through the turbine wheel blank space before reaching the halls of the second stage turbine blade. The collision that resulted in hydraulic losses of water jet and changes in the direction of the water jet when it enters the halls of the second stage turbine blade, and such conditions are predictable reduces the efficiency [20-22]. Based on the photographs in Fig. 2 it can be stated that the steady stream of water, leaving the turbine outer side with a $120^{\circ}$ entry arc, spreads larger than the steady stream of water leaving the turbine outer side with a $90^{\circ}$ entry arc nozzle. Fig. 2 also shows the photographs of the steady stream of water, leaving the outskirt of the turbine wheel with the nozzle that has a 90 degree entry arc deploys larger than the steady stream of water, leaving the outer side of the turbine wheel with the nozzle that has an entry arc of 75 degrees.

The efficiency of the turbines in this experimental study is 82 percent for the turbine with a 75 degree entry arc, 88 percent for the turbine with a 90 degree entry arc and 30 percent for the turbine with a 120 degree entry arc.

5. 3. Visualization of water flowing through empty space inside of turbine runner and efficiency of the models tested at $150 \mathrm{rpm}$

Fig. 4 is well equipped with the photographs showing a visualization of the trace of water flowing through inside of the turbine models for the entry arc of $\theta=75^{\circ}, \theta=90^{\circ}$ dan $\theta=120^{\circ}$.

The photos of Fig. 4 show the jet of water leaving the halls of the first stage turbine blade, spread and bump into each other, then some of this water hit the shaft during flow through the turbine wheel blank space before reaching the halls of the second stage turbine blade [23-25].

Fig. 4 is well equipped with the photographs showing a visualization of the trace of water flowing through inside of the turbine models for the entry arc of $\theta=75^{\circ}, \theta=90^{\circ}$ dan $\theta=120^{\circ}$.

The photos of Fig. 4 show the jet of water leaving the halls of the first stage turbine blade, spread and bump into 
each other, then some of this water hit the shaft during flow through the turbine wheel blank space before reaching the halls of the second stage turbine blade [23-25]. The collision that resulted in hydraulic losses of water jet and changes in the direction of the water jet when it enters the halls of the second stage turbine blade, and such conditions are predictable reduces the efficiency [26-28]. Based on the photographs in Fig. 3 it can be stated that the steady stream of water, leaving the turbine outer side with a $120^{\circ}$ entry arc, spreads larger than the steady stream of water leaving the turbine outer side with a $90^{\circ}$ entry arc nozzle. Fig. 3 also shows the photographs of the steady stream of water, leaving the outskirt of the turbine wheel with the nozzle that has a 90 degree entry arc deploys larger than the steady stream of water, leaving the outer side of the turbine wheel with the nozzle that has an entry arc of 75 degrees.

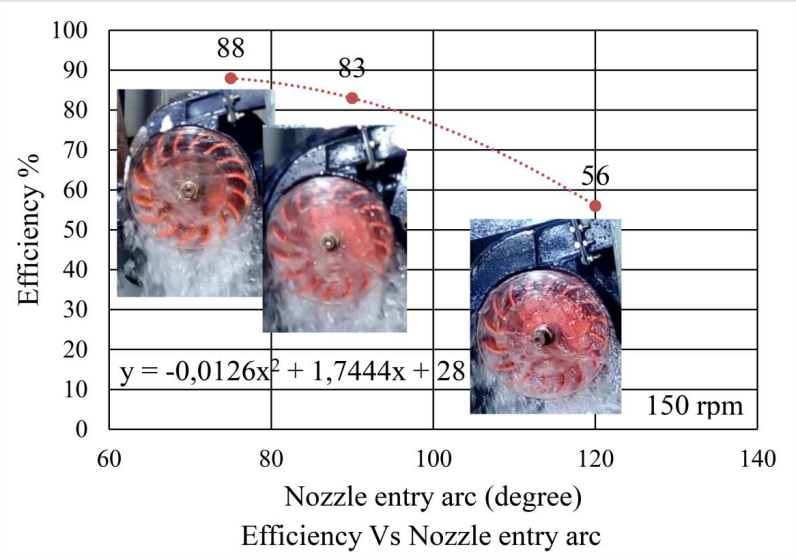

Fig. 4. Efficiency Vs Nozzle entry arc at the rotational speed of $150 \mathrm{rpm}$

The efficiency of the turbines in this experimental study is 88 percent for the turbine with a 75 degree entry arc, 83 percent for the turbine with a 90 degree entry arc and 56 percent for the turbine with a 120 degree entry arc.

5. 4. Visualization of water flowing through empty space inside of turbine runner and efficiency of the models tested at $250 \mathrm{rpm}$

Fig. 5 is well equipped with the photographs showing a visualization of the trace of water flowing through inside of the turbine models for the entry arc of $\theta=75^{\circ}, \theta=90^{\circ}$ dan $\theta=120^{\circ}$.

Fig. 5 shows the relation of nozzle entry arc versus efficiency equipped with the photograph of the water jets condition inside the turbine wheels when the turbine runs at $250 \mathrm{rpm}$. The jets of water, leaving the halls of the first stage turbine blade do not hit the shaft during flow through the turbine wheel blank space before reaching the halls of the second stage turbine blade. All the jets of water come into the halls of the first stage and strike the blades of the first stage, then pass through the empty space and hit the blades of the second stage and finally the water leaves the runner.

Fig. 5 is well equipped with the photographs showing a visualization of the trace of water flowing through inside of the turbine models for the entry arc of $\theta=75^{\circ}, \theta=90^{\circ}$ dan $\theta=120^{\circ}$.

Fig. 5 shows the relation of nozzle entry arc versus efficiency equipped with the photograph of the water jets condition inside the turbine wheels when the turbine runs at $250 \mathrm{rpm}$. The jets of water, leaving the halls of the first stage turbine blade do not hit the shaft during flow through the turbine wheel blank space before reaching the halls of the second stage turbine blade. All the jets of water come into the halls of the first stage and strike the blades of the first stage, then pass through the empty space and hit the blades of the second stage and finally the water leaves the runner.

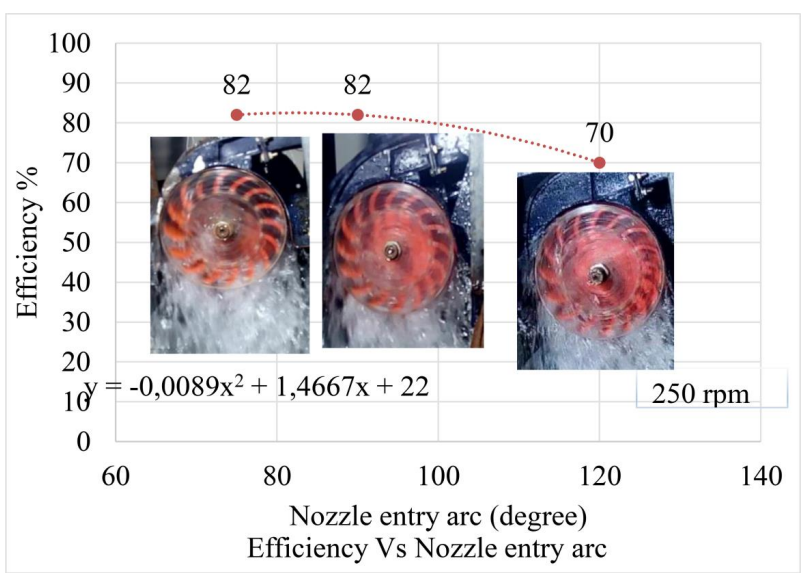

Fig. 5. Efficiency Vs Nozzle entry arc at the rotational speed of $250 \mathrm{rpm}$

All the jets of water that goes into the blade halls on the first stage after hitting the blades of the first stage, next passes through the empty space, then hit the second stage blades and finally the water leaves the runner. There are small collisions in the empty space that resulted in small hydraulic losses of water jet and little changes in the direction of the water jet when it enters the halls of the second stage turbine blade, and such conditions are predictable fix the efficiency of the turbine. Based on the photographs in Fig. 5 it can be stated that the angle of spreading of the streams of water, leaving the outer rim of the runner with the nozzle having the entry arc of 120 degrees is larger compared to the spreading angle of the flow of water leaving the outer rim of the runner with the nozzle having the entry arc of 90 degrees. Fig. 4 also shows the photographs of the steady stream of water, leaving the outskirt of the turbine wheel with the nozzle that has a 90 degree entry arc deploys larger than the steady stream of water, leaving the outer side of the turbine wheel with the nozzle that has an entry arc of 75 degrees.

The efficiency of the turbines in this experimental study is 82 percent for the turbine with a 75 degree entry arc, 82 percent for the turbine with a 90 degree entry arc and 70 percent for the turbine with a 120 degree entry arc.

\subsection{Visualization of water flowing through empty} space inside of turbine runner and efficiency of the models tested at $300 \mathrm{rpm}$

Fig. 6 is well equipped with the photographs showing a visualization of the trace of water flowing through inside of the turbine models for the entry arc of $\theta=75^{\circ}, \theta=90^{\circ}$ dan $\theta=120^{\circ}$.

The photos of Fig. 6 show the jet of water, leaving the halls of the first stage turbine blade not hitting the shaft and at the position far from the shaft during flow through the inside turbine wheel blank space before reaching the halls of the second stage turbine blade. 


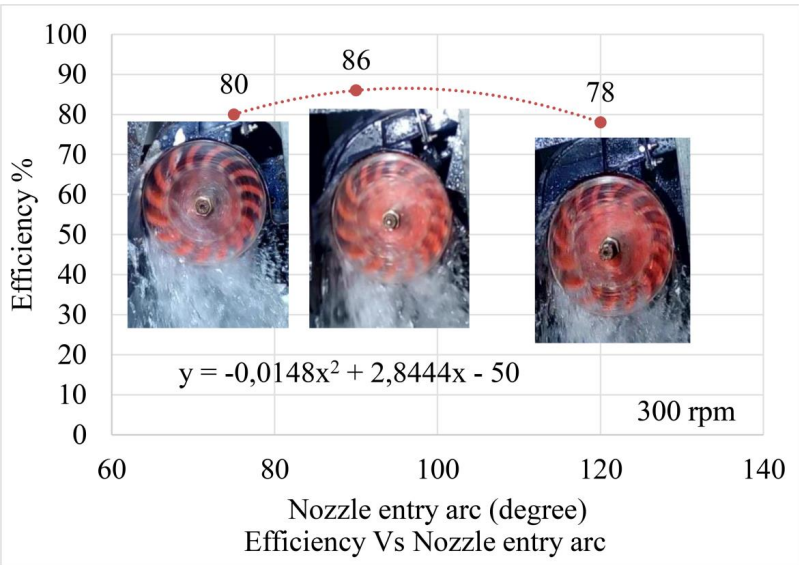

Fig. 6. Efficiency Vs Nozzle entry arc at the rotational speed of $300 \mathrm{rpm}$

There is a small collision that resulted small in hydraulic losses of water jet and little changes in the direction of the water jet when it enters the halls of the second stage turbine blade, and such conditions are predictable improve the efficiency of the turbine. Based on the photographs in Fig. 6 it can be stated that the steady stream of water, leaving the outer side of the turbine wheel with the nozzle that has a 120-degree entry arc spreads larger than the steady stream of water, leaving the outer side of the turbine wheel with the nozzle that has a 90 degree entry arc. Based on the photographs in Fig. 6 it can be stated that the steady stream of water, leaving the turbine outer side with a $90^{\circ}$ entry arc, spreads larger than the steady stream of water leaving the turbine outer side with a $75^{\circ}$ entry arc nozzle. The water jets flowing inside the runner with a 120 degree entry arc are more in irregular condition than that of water jets flowing inside the runner with a 90 and 75 degree entry arcs. And the patterns of water jets flowing inside the runner with a 75 degree entry arc are more in irregular conditions than that of water jets flowing inside the runner with a 90 degree entry arc. Therefore, the flow pattern of water jets inside the runner entering the blade passages of the second stage of the model with a 90 degree entry arc is the best compared to the flow pattern of water jets inside the runner entering the blade passages of the second stage of the model with a 90 and 75 degree entry arcs.

The efficiency of the turbines in this experimental study is 80 percent for the turbine with a $75^{\circ}$ entry arc, 86 percent for the turbine with a $90^{\circ}$ entry arc and 78 percent for the turbine with a $120^{\circ}$ entry arc.

5.6. Visualization of water flowing through empty space inside of turbine runner and efficiency of the models tested at $500 \mathrm{rpm}$

Fig. 7 is well equipped with the photographs showing a visualization of the trace of water flowing through inside of the turbine models for the entry arc of $\theta=75^{\circ}, \theta=90^{\circ}$ and $\theta=120^{\circ}$.

Fig. 7 is well equipped with the photographs showing a visualization of the trace of water flowing through inside of the turbine models for the entry arc of $\theta=75^{\circ}, \theta=90^{\circ}$ and $\theta=120^{\circ}$.

Based on the photographs in Fig. 7 it can be stated that the steady stream of water, leaving the turbine outer side with a $90^{\circ}$ entry arc, spreads larger than the steady stream of water leaving the turbine outer side with a $90^{\circ}$ entry arc nozzle. There are still small collisions that resulted small in hydraulic losses of water jet and little changes in the direction of the water jet when it enters the halls of the second stage turbine blade, and such conditions are still resulting in the considerable efficiency of the turbine. It is important to note that when the turbine rotates at $500 \mathrm{rpm}$, not all water jets after hitting the blades of the first stage flow through the empty space of the turbine wheel, where some jets of water after hitting the blades of the first stage directly leave the wheel. So these jets of water leave the runner without hitting the blades of the second stage and as a result the water does not contribute to an increase in the shaft power by converting its kinetic energy into mechanical energy [29-31]. In addition, the figure shows that the water jet flowing through the empty space of the model with a nozzle entry arc of $120^{\circ}$ is thinner than the water jet flowing through the empty space of the model with a nozzle entry arc of $90^{\circ}$ and the water jet flowing through the empty space of the model with a nozzle entry arc of $90^{\circ}$ is thinner than the water jet flowing through the empty space of the model with a nozzle entry arc of $75^{\circ}$. The thickness of water jets flowing through the empty space combined with the width of the runner indicates the amount of water through the empty space, the bigger nozzle entry arc the smaller jets of water striking the active blade of the second stage [32-34]. Further, it can be stated that the amount of water jets flowing through the empty space and then strike the blades of the second stage results in a tangential force [35-37].

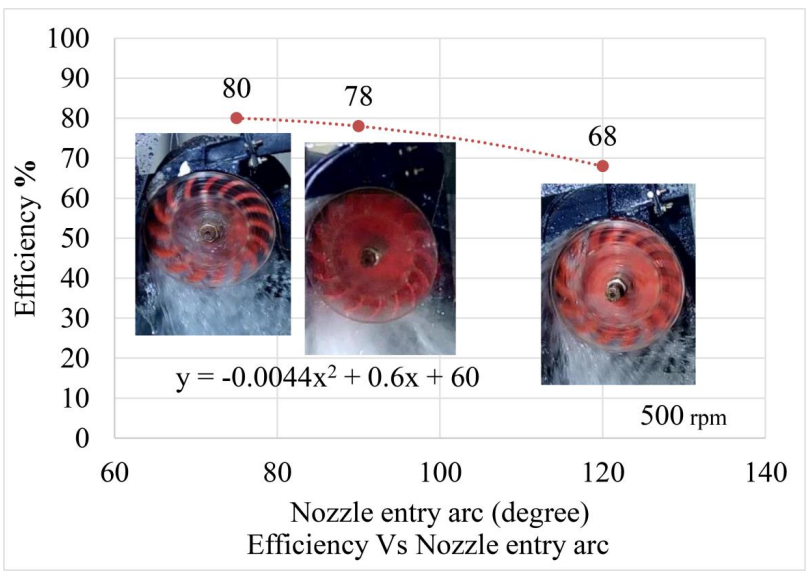

Fig. 7. Efficiency Vs Nozzle entry arc at the rotational speed of $500 \mathrm{rpm}$

Furthermore, based on the photographs in Fig. 7 it can be stated that the steady stream of water leaving the outer side of the turbine wheel with the nozzle that has a 120-degree entry arc spreads in a larger jets area than the steady stream of water leaving the outer rim of the turbine runner having a 90 degree entry arc. Fig. 6 also shows the photographs of the steady stream water, leaving the turbine outer side with a $90^{\circ}$ entry arc, deploys larger than the steady stream of water leaving the turbine outer side with a $75^{\circ}$ entry arc nozzle.

This study shows that when the model runs at $500 \mathrm{rpm}$, the nozzle entry arcs influence the pattern of water flow passing through the runner and finally determine the efficiency of the turbine. The efficiency of the turbines in this experimental study is 80 percent for the turbine with a 75 degree entry arc, 78 percent for the turbine with a 90 degree entry arc and 68 percent for the turbine with a 120 degree entry arc. 


\section{Discussion of the flow visualization of water jet passing through the empty space of cross-flow turbine runner}

The findings of this study are the relationship between the turbine rotation, flow conditions and cross-flow turbine efficiency. The relationship between these cross-flow turbine parameters will be the basis for making decisions to determine optimal turbine operating parameters.

Rotation of a turbine is an important parameter in the operation of a micro-hydro power plant, a power plant using a turbine with rotational speed, lower than the rotational speed of the generator system must then be equipped with a speed increase connecting the turbine to the generator so that the generator operated at normal rotation. In addition, the lower turbine rotation the higher speed ratio of speed increase needed or, on the other hand, the higher turbine rotation the lower speed ratio of speed increase equipped with a micro-hydro power plant

The results of the experimental study indicate that the efficiency of the cross-flow turbine is influenced by both the nozzle entry arc and the rotational speed of the runner. The magnitude of the nozzle entry arc determines the number of blade hallways where a steady stream of water enters the turbine wheel, so that the larger the nozzle entry arc the greater the number of blade hallways in which the water jets flows through. The number of blade hallways flowed with the water affects the pattern of water jets flowing through the empty space, further, the pattern of the jets determines the magnitude of hydraulic losses and finally influences the efficiency of the turbine. Further, it can be stated that the greater the nozzle entry arc the greater the number of water jets flowing through the empty space which then collide with each other, result in the larger hydraulic losses, therefore, generally result in the lower efficiency.
The rotational speed of the water turbine determines the peripheral velocity of the runner, the higher rotational speed of the runner results in the higher runner peripheral velocity. The peripheral velocity determines the period of the water jets entering one blade hallways, since the velocity of water jets remains constant, so the amount of water flowing through one hallway depends on the rotational speed. The higher the rotational speed of the runner, the less water flowing through one blade hallway, while the higher the rotational speed of the runner the greater the number of blade hallways flowed with water. The turbine efficiency is the ratio of shaft horsepower and water horsepower, since shaft horsepower is a function of force acted by the water and rotational speed of the runner, so the condition of water strike on the runner blades determines the turbine efficiency. The number of blades on the crossflow turbine shaft affects the performance of cross-flow turbines. Likewise with the turbine rotation. It was concluded that the greater the number of blades the higher the turbine efficiency.

\section{Conclusions}

1. The pattern of flowing water through the runner is influenced by the magnitude of the entry arc and rotational speed of the runner.

2. The turbine wheel spinning lower than $150 \mathrm{rpm}$ is the condition of the water flow inside the turbine runner hitting the shaft. The higher the rotation of the turbine wheel, the farther the distance of the water flow in the turbine wheel against the axis turbine.

3. The efficiency of the turbine is influenced by the magnitude of the entry arc and rotational speed of the runner.

\section{References}

1. Government Gazette Republic of Namibia. URL: https://namiblii.org/system/files/gazette/2018/6670/\%236670-Gov\%20N163.pdf

2. Guidelines for determining flood flow frequency - Bulletin 17C / England J. F., Cohn T. A., Faber B. A., Stedinger J. R., Thomas W. O., Veilleux A. G. et. al. // Techniques and Methods. 2018. doi: https://doi.org/10.3133/tm4b5

3. Thin Layer Chromatography // Chemistry LibreTexts. 2019. URL: https://chem.libretexts.org/Ancillary_Materials/Demos\%2C_ Techniques\%2C_and_Experiments/General_Lab_Techniques/Thin_Layer_Chromatography

4. Childress S. Walking on water // Journal of Fluid Mechanics. 2010. Vol. 644. P. 1. doi: https://doi.org/10.1017/s0022112009993107

5. Owusu-Boateng G., Adjei V. The potential utilization of grey water for irrigation: A case study on the Kwame Nkrumah University of Science and Technology, Kumasi Campus // Journal of Applied Research in Water and Wastewater. 2014. Vol. 1, Issue 1. P. 31-37.

6. Wacławczyk T., Koronowicz T. Comparison of cicsam and hric high-resolution schemes for interface capturing // Journal of Theoretical and Applied Mechanics. 2008. Vol. 46, Issue 2. P. 325-345.

7. Real-Gas Effects in Organic Rankine Cycle Turbine Nozzles / Colonna P., Harinck J., Rebay S., Guardone A. // Journal of Propulsion and Power. 2008. Vol. 24, Issue 2. P. 282-294. doi: https://doi.org/10.2514/1.29718

8. Pasquale D., Ghidoni A., Rebay S. Shape Optimization of an Organic Rankine Cycle Radial Turbine Nozzle // Journal of Engineering for Gas Turbines and Power. 2013. Vol. 135, Issue 4. P. 042308. doi: https://doi.org/10.1115/1.4023118

9. Failure analysis of a gas turbine nozzle / Mazur Z., Hernandez-Rossette A., Garcia-Illescas R., Luna-Ramirez A. // Engineering Failure Analysis. 2008. Vol. 15, Issue 7. P. 913-921. doi: https://doi.org/10.1016/j.engfailanal.2007.10.009

10. Effect of nozzle type, size and pressure on spray droplet characteristics / Nuyttens D., Baetens K., De Schampheleire M., Sonck B. // Biosystems Engineering. 2007. Vol. 97, Issue 3. P. 333-345. doi: https://doi.org/10.1016/j.biosystemseng.2007.03.001

11. Hagena O. F., Obert W. Cluster Formation in Expanding Supersonic Jets: Effect of Pressure, Temperature, Nozzle Size, and Test Gas // The Journal of Chemical Physics. 1972. Vol. 56, Issue 5. P. 1793-1802. doi: https://doi.org/10.1063/1.1677455

12. Chang R., Nam J., Sun W. Effects of Dispensing Pressure and Nozzle Diameter on Cell Survival from Solid Freeform Fabrication-Based Direct Cell Writing // Tissue Engineering Part A. 2008. Vol. 14, Issue 1. P. 41-48. doi: https://doi.org/10.1089/ ten.a.2007.0004 
13. Nozzles: Selection and sizing / Grisso R., Hipkins P., Askew S. D., Hipkins L., Mccall D. College of Agriculture and Life Sciences, Virginia Polytechnic Institute and State University, 2013. URL: https://www.pubs.ext.vt.edu/content/dam/pubs_ext_vt_ edu/442/442-032/442-032_pdf.pdf

14. Kanoğlu M. Cryogenic turbine efficiencies // Exergy, An International Journal. 2001. Vol. 1, Issue 3. P. 202-208. doi: https:// doi.org/10.1016/s1164-0235(01)00026-7

15. Poullikkas A. An overview of current and future sustainable gas turbine technologies // Renewable and Sustainable Energy Reviews. 2005. Vol. 9, Issue 5. P. 409-443. doi: https://doi.org/10.1016/j.rser.2004.05.009

16. Kacker S. C., Okapuu U. A Mean Line Prediction Method for Axial Flow Turbine Efficiency // Journal of Engineering for Power. 1982. Vol. 104, Issue 1. P. 111. doi: https://doi.org/10.1115/1.3227240

17. Safarian S., Aramoun F. Energy and exergy assessments of modified Organic Rankine Cycles (ORCs) // Energy Reports. 2015. Vol. 1. P. 1-7. doi: https://doi.org/10.1016/j.egyr.2014.10.003

18. Vennell R. Realizing the potential of tidal currents and the efficiency of turbine farms in a channel // Renewable Energy. 2012. Vol. 47. P. 95-102. doi: https://doi.org/10.1016/j.renene.2012.03.036

19. Garrett C., Cummins P. The efficiency of a turbine in a tidal channel // Journal of Fluid Mechanics. 2007. Vol. 588. doi: https:// doi.org/10.1017/s0022112007007781

20. Tiwari A. K., Hasan M. M., Islam M. Effect of ambient temperature on the performance of a combined cycle power plant // Transactions of the Canadian Society for Mechanical Engineering. 2013. Vol. 37, Issue 4. P. 1177-1188. doi: https://doi.org/10.1139/ tcsme-2013-0099

21. Gorban' A. N., Gorlov A. M., Silantyev V. M. Limits of the Turbine Efficiency for Free Fluid Flow // Journal of Energy Resources Technology. 2001. Vol. 123, Issue 4. P. 311. doi: https://doi.org/10.1115/1.1414137

22. Barthelmie R. J., Jensen L. E. Evaluation of wind farm efficiency and wind turbine wakes at the Nysted offshore wind farm // Wind Energy. 2010. Vol. 13, Issue 6. P. 573-586. doi: https://doi.org/10.1002/we.408

23. Wind Turbine Blade Aerodynamics. URL: http://kimerius.com/app/download/5784129509/Wind+turbine+blade+aerodynamics.pdf

24. Poursaeidi E., Aieneravaie M., Mohammadi M. R. Failure analysis of a second stage blade in a gas turbine engine // Engineering Failure Analysis. 2008. Vol. 15, Issue 8. P. 1111-1129. doi: https://doi.org/10.1016/j.engfailanal.2007.11.020

25. Steam turbine blade failure analysis / Mazur Z., Garcia-Illescas R., Aguirre-Romano J., Perez-Rodriguez N. // Engineering Failure Analysis. 2008. Vol. 15, Issue 1-2. P. 129-141. doi: https://doi.org/10.1016/j.engfailanal.2006.11.018

26. Efficiency Improvement of Vertical Axis Wind Turbines with an Upstream Deflector / Stout C., Islam S., White A., Arnott S., Kollovozi E., Shaw M. et. al. // Energy Procedia. 2017. Vol. 118. P. 141-148. doi: https://doi.org/10.1016/j.egypro.2017.07.032

27. Sarkar A., Behera D. K. Wind Turbine Blade Efficiency and Power Calculation with Electrical Analogy // International Journal of Scientific and Research Publications. 2012. Vol. 2, Issue 2.

28. Padture N. P. Thermal Barrier Coatings for Gas-Turbine Engine Applications // Science. 2002. Vol. 296, Issue 5566. P. 280-284. doi: https://doi.org/10.1126/science.1068609

29. Recast layer removal after electrical discharge machining via Taguchi analysis: A feasibility study / Wang C.-C., Chow H.-M., Yang L.-D., Lu C.-T. // Journal of Materials Processing Technology. 2009. Vol. 209, Issue 8. P. 4134-4140. doi: https:// doi.org/10.1016/j.jmatprotec.2008.10.012

30. Liu C., Jiang D. Crack modeling of rotating blades with cracked hexahedral finite element method // Mechanical Systems and Signal Processing. 2014. Vol. 46, Issue 2. P. 406-423. doi: https://doi.org/10.1016/j.ymssp.2014.01.007 